\title{
Learning with computers: Generating insights into the development of cognitive tools using cultural historical activity theory
}

\author{
Seng-Chee Tan \\ National Institute of Education, Nanyang Technological University
}

\begin{abstract}
Using computers as cognitive tools or mindtools has created impact in education since their introduction in the 1990s. One main characteristic is the notion of learning with computers as intellectual partners: engaging learners in higher level thinking while taking away the lower level cognitive load such as computing and digital storage. In recent years, the element of social interactions has been integrated, leading to the development of social cognitive tools or social mindtools. However, the differences between and underlying values of these applications may not be apparent. This article applies cultural historical activity theory (CHAT) to analyse these developments so as to generate insights into the nuanced differences among various applications, including the roles of computers in distributed cognition within an activity system. CHAT can be applied to analyse contradictions within and beyond an activity system, which can help to identify opportunities for innovation and enhancement to the system.
\end{abstract}

\section{Introduction}

This article aims to clarify the characteristics and values of various ways of learning with computers, using cultural historical activity theory (CHAT) (Cole \& Engeström, 1993; Engeström, 1987) as an analytical lens. CHAT provides an appropriate framework to analyse an activity system that depicts how a group of participants work on a common goal, the tools used and the rules and division of roles. Details of CHAT will be provided in the Methods section.

Using computers as a tutor (Taylor, 1980) to mimic the roles of an instructor, as in the case of various computer-assisted instruction programs, has been a predominant approach in integrating technologies into education. Typically, a computer-assisted instruction program starts with a set of predefined learning objectives and pre-programmed sequences of instructional activities, coupled with assessment of a learner's progress, which aims at helping learners acquire knowledge. With the advancement in computer technologies and cognitive sciences, intelligent tutoring systems (ITSs) were developed to provide flexible and customised learning pathways based on learners' performance and behaviours. In recent years, the development of massive open online courses (MOOCs) (Li, Sun, \& Sun, 2018) has gained popularity among educators and learners for their accessibility. Regardless of the advancement in technologies, ITSs and most MOOCs are still functioning in their similar mode of using computers as a tutor, focusing on students' learning from computers; that is, computers play the role of instructors, and computing intelligence is invested in making these roles more human like, for example, in optimising learning pathways for learners.

However, using computers as tutors has its fair share of criticisms, for example, for neglecting design for social interactions among learners and lacking attention to the social presence of tutor and peers (Stahl, Koschmann, \& Suthers, 2015). Using computers as tutors is also operating with the assumption that knowledge can be chunked into discrete units of facts and that learning means acquiring these facts; in other words, treating learning as acquisition of knowledge (Sfard, 1998). In this regard, using computers as cognitive tools or mindtools offers refreshing alternative approaches that help educators break away from the tyranny of computers controlling learners and replacing tutors. Just like a physical tool that helps humans do work, computers can aid humans in thinking. Various terms have been used for these related applications, such as cognitive technologies (Pea, 1985), technologies of the mind (Salomon, Perkins, \& Globerson, 1991), cognitive tools (Kommers, Jonassen, \& Mayes, 1992), and mindtools (Jonassen, 1996, 2000). Among these tools, a sub-category known as social cognitive tools (e.g., Scardamalia \& Bereiter, 1996) or social mindtools (e.g., Nuutinen, Sutinen, Botha \& Kommers, 2010) has also emerged.

Despite the fact that the concept of cognitive tools or mindtools emerged in the late 1980s, more than two decades later, M. C. Kim (2012), in revisiting the use of cognitive tools for science education, raised three 
issues concerning research on cognitive tools. First, there is a need to clearly define what a cognitive tool is; second, there should be research examining the distribution of knowledge mediated with cognitive tools; third, more research could be devoted to examining the contextual applications of cognitive tools. These issues, including the need to clarify the definition of cognitive tools, could be an indication of the continual evolution of the field and the emergence of new concepts and tools that redefine the notion of learning with computers. How do we make sense of these developments? What are their values and how do we further advance the research and development of these tools and their applications? This article aims to address some of these issues, focusing on the overarching research question: "What are the characteristics of the activity systems related to learning with computers, including the use of computers as mindtools, as cognitive tools, and as social mindtools or social cognitive tools?" The analyses were guided by the following sub-questions:

For each type of application,

(1) What does a typical activity system look like?

(2) What are the underlying motives and theories about learning?

(3) What are the tools used? What roles do the tools play?

(4) Are there differences among the use of computers as mindtools, computers as cognitive tools, and computers as social mindtools or social cognitive tools?

In addition to these analytical questions, how do we innovate and improve these applications?

\section{Methods}

This article, a synthesis of published academic works, aims to clarify the concepts and development of learning with computers, epitomised by using computers as cognitive tools or mindtools. It is not a systematic review of empirical studies; rather, it is aligned to the research synthesis method called qualitative synthesis of research (Suri \& Clarke, 2009). This synthesis method uses a more inclusive lens with which to analyse various types of academic publications, including non-research papers. This method is relevant to this article, which has a specific focus on the major developments in and theoretical discussion of learning with computers, which are also presented in non-empirical studies.

A search was conducted via EBSCO Discovery service, which includes several databases (e.g., PsyArticles and ProQuest), using the search terms (TI "cognitive tool?" or "mindtool?") and "education" and (computer? or technology or software), limited to scholarly peer-reviewed articles in the English language. There were 143 articles identified; each article was reviewed focusing on those that provide theoretical bases for the use of the tools. Snowball method was used to identify other relevant articles. The References section (57 items) lists the articles selected, including some empirical studies that were used to provide examples of the applications.

Methodologically, to make sense of the various applications and developments in the evolution of learning with computers, this article adopted CHAT (Cole \& Engeström, 1993; Engeström, 1987) as a framework for the analysis. CHAT is a framework that examines the human activities of individuals in an associated social community. An activity is an object-oriented structure that is shaped by a culture (Engeström, 1999); it is a conscious process driven by a motive (Engeström, 1999; Kozulin, 1986); and it consists of chains of actions directed at some goals, which, in turn, are made up of a series of operations (specific acts) that are afforded by the available conditions in the environment. For example, a classroom activity using a concept mapping tool could be driven by the goal of enhancing students' critical thinking; the use of the concept mapping tool also reflects the beliefs and values of the teachers using this pedagogical approach. The teachers could implement a series of actions (e.g., teaching how to use a concept map, providing examples, setting a concept mapping assignment) as short-term goals that aim at achieving the outcome of learning with constructing a concept map. The teacher then performs a series of operations (e.g., communicating instructions).

Engeström (1987) proposed an activity system that has six core components depicted as nodes of a triangle (see Figure 1). The top three elements show how a subject (or an actor) acting on an object (a focused entity) to achieve the desired outcome that is mediated by the tool(s). Tools can be physical (e.g., a whiteboard) or conceptual cultural artefacts (e.g., language, protocols). For example, a student (subject) 
uses a tool (a computer-based tutorial) to learn about a topic (object) to achieve deeper understanding of a topic (outcome). The fourth component is the community, comprising others who share a common interest in working on the object. Mediating between the subject and the community are rules that regulate how the subject relates to or works with other participants in the community. Division of labour describes the roles of members in the community when working on the object. Figure 1 shows an example of the activity system depicting learning from computers using a computer-based tutorial program.

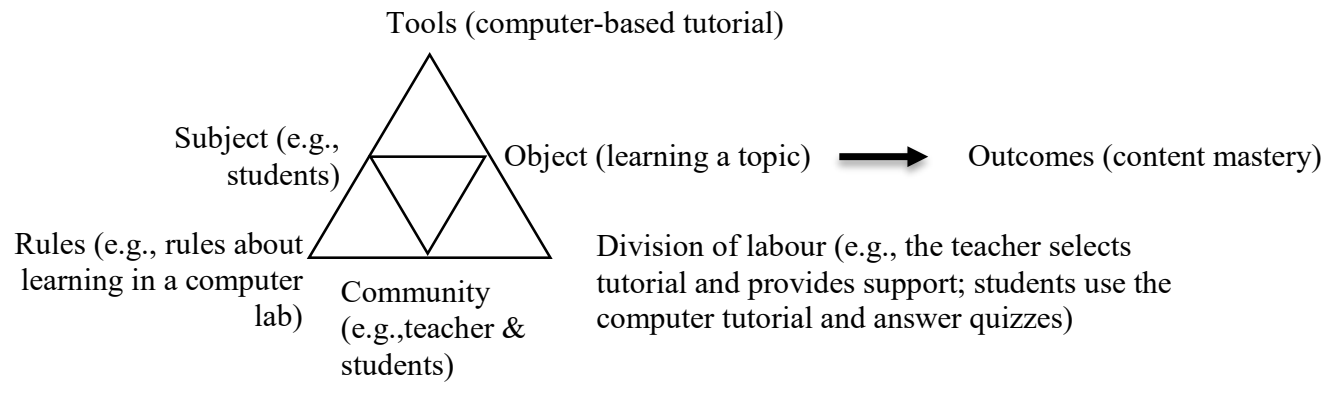

Figure 1. An activity system of using a computer-based tutorial (adapted from Engeström, 2001, p. 135)

CHAT was chosen as the framework for analysing various applications of learning with computers because it directs one's attention to the main actors in an activity system, the mediating tools used, and the objects the actors are working on. It also helps us in identifying the underlying rules and division of roles. Given that the distribution of roles (between machines and people and among people) is an important consideration in the applications of mindtools or cognitive tools, CHAT is an appropriate framework for the purpose of this article.

\section{Analysis of mindtools, cognitive tools, and social mindtools or social cognitive tools using CHAT}

In this section, CHAT is used to analyse three major ways of using computers as tools in the following order: computers as mindtools, as cognitive tools, and as social mindtools or social cognitive tools.

Activity systems of using computers as mindtools

Mindtools are "computer-based tools and learning environments that have been adapted or developed to function as intellectual partners with the learner in order to engage and facilitate thinking and higher order learning" (Jonassen, 2000, p. 9), for example, using a semantic networking tool (e.g., CMap, https://cmap.ihmc.us/) for concept mapping. Concept mapping, a technique developed by Novak and Gowin (1984), requires a learner to identify the key concepts of a topic, represent the concepts with the correct concept labels, link a concept with related concepts, label the relationships between pairs of concepts, and sometimes arrange the concepts in hierarchical order. Although concept mapping can be done using the paper-and-pencil method, a semantic networking tool provides digital storage and retrieval; ease of addition, revision and expansion; ease of cross-linking; ease of collaboration; and machine calculations of metrics related to the maps for feedback.

Figure 2 shows the typical activity system of an application of mindtools in a classroom, represented by the use of a concept mapping tool. Underpinning the use of computers as mindtools are distributed cognition and Vygotsky's (1978) social constructivist theory, particularly mediation of cognition by cultural artefacts or tools. Following Vygotsky's theory, the partnership with tools or cultural artefacts to achieve what an individual would otherwise not be able to achieve is but a step towards individuals internalising the thinking and developing the competency to carry out the intellectual activity independently. Pea (1993) suggested that most of our intellectual activities are enacted through some extent of distribution between the person and cultural artefacts or tools (e.g., use of the paintbrush by a painter) such that it is sometimes impossible to separate our cognition as activities independent from cultural artefacts and tools. 
Applying the lens of distributed cognition, B. Kim and Reeves (2007) suggested that mindtools mediate between the subject (a learner) and the object, and there is a distribution of roles between computers as tools and learners.

The value of mindtools can be illustrated by contrasting them with the use of computer-assisted instruction. In computer-assisted instruction programs, the computers are programmed to mimic instructors by providing instruction and assessing learners. Content for learning has to be hard-coded into the system, and some forms of intelligence can be embedded to reveal the content in bite sizes, in different modalities, and different sequences. The learners' roles are to follow the instructions, perform the learning activities, and answer the quizzes. Mindtools, however, work differently. The computer provides the digital tool or environment, stores the data, and uses programmed algorithms for calculations (e.g., metrics for a concept map); the learners, on the other hand, have to do the hard work of cognitive activities like critical thinking. Jonassen (2000) argued that using computers as mindtools engages learners in the most crucial aspects of learning (critical thinking and meaningful learning), while computers perform the parts that computing devices are designed for (i.e., computing). It is an intellectual partnership that focuses on learning. In short, the critical difference between a mindtool and a computer-assisted instruction program is that a mindtool acts as an intellectual partner to engage learners in thinking, while the latter is a teaching tool that helps to deliver instruction (an efficiency tool). Pea (1985) further elaborated the roles of computer tools in restructuring a learner's thinking. A concept mapping tool, for example, constrains the way the knowledge is represented (e.g., a user should use concept labels) and engages the learners in critical thinking (e.g., identify relationships) which will not occur naturally. In this sense, mindtools are not fingertip tools (Perkins, 1985) that learners use effortlessly; they actually make the learners think harder.

Most mindtools used are domain general tools (B. Kim \& Reeves, 2007) that can be applied for learning of various subject disciplines (e.g., sciences and humanities). However, not all domain general tools are mindtools. Jonassen (2000) differentiated between a mindtool (e.g., a concept mapping tool) and a productivity tool (e.g., word processing software) in that the productivity tool helps us in doing work efficiently, but not necessarily engaging us in thinking. Thus, productivity tools that increase work efficiency are not mindtools.

Underpinning the use of computers as mindtools is the constructivist philosophy of learning. Duffy and Jonassen (1992) explained the differences between objectivist and constructivist epistemologies and how they affect the way technologies are used in education. In computer-assisted instruction programs, there is an assumption that learning is a process of achieving complete understanding of the correct structure, properties, and relationships of the world out there. The goal of instruction is to transmit this objective truth, and objective tests can be set to assess the extent of knowledge gained by the learners. Different interpretations of the objective knowledge mean partial or biased understanding. In contrast, constructivist epistemology (Bednar, Cunningham, Duffy, \& Perry, 1992) acknowledges the existence of the external world, but the structure, properties, and relationships are subject to interpretation, which can vary in different cultures and contexts. Learning is helping learners to get to know the socially constructed and sanctioned knowledge in a community. Thus, experience and meaning making are a critical part of the learning process. Getting learners to represent their knowledge using mindtools is one of the ways of engaging them in the critical process of meaning making.

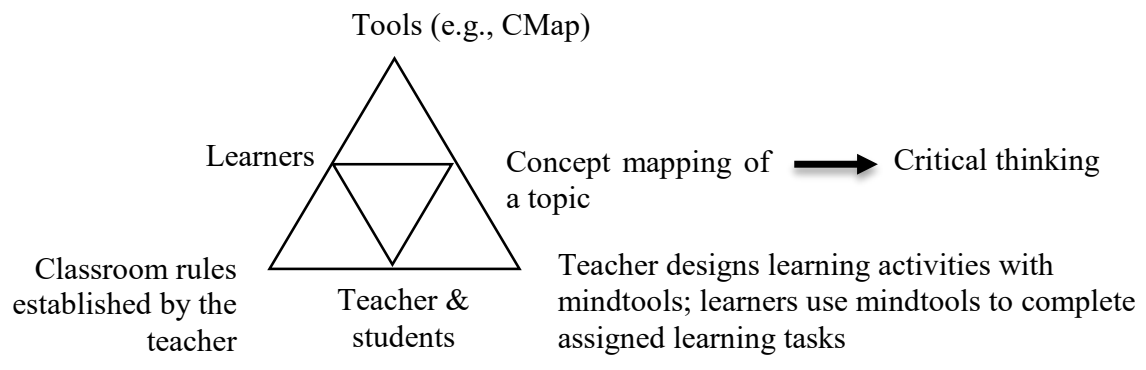

Motive: Develop critical thinking through constructivist learning

Figure 2. An example of an activity system of using CMap as a mindtool 
Activity systems of using computers as cognitive tools

Pursuing a similar line of argument of using tools to support learning, another group of researchers proposed the use of computers as cognitive tools. The concepts of mindtools and cognitive tools are similar but with some minor differences in research tradition and implementation approach. While Jonassen (1996, 2000) came from the tradition of instructional design, using computers as cognitive tools (see Lajoie, 2000; Lajoie \& Derry, 1993) was initiated by researchers in the field of artificial intelligence and cognitive science. Using computers as cognitive tools (Lajoie, 2000; Lajoie \& Derry, 1993) was proposed as an alternative to modelling students' thinking processes as in the case ITSs. Lajoie and Derry (1993) saw the limitations of ITSs, such as the impossibility of modelling all possible thinking processes. Critically, using computers as an intelligent tutor deprives the students agency in setting their own goals and assessing their own performance. Thus, the proponents of using computers as cognitive tools follow similar cognitive task analyses of thinking processes, just like the researchers in ITSs, but they use the analyses for unintelligent tutoring systems that scaffold (rather than diagnose and prescribe) students' thinking. One example of using computers as cognitive tools is the Writing Partner (Salomon, 1993). Building on the analyses of the psychology and procedures of composition writing by Bereiter and Scardamalia (1987), the Writing Partner offers four kinds of support by providing a planning and outline tool, guiding questions during the writing process, a pull-down menu for assistance when a learner is stuck in the writing, and memory support in terms of retrieving the key ideas and outlines. Another example is HERON (Reusser, 1993), which focused on helping elementary school children solve mathematics word problems (a type of mathematics exercise with a substantial part of the background information of the problem presented as text). Based on cognitive task analyses of solving word problems, HERON was developed as a graphical interface tool that helps a learner identify relevant quantitative values and units in a word problem, relate these quantitative variables according to the text description of the word problem, and finally translate them into appropriate equations.

Salomon (1993) articulated the twin goals of using computers as cognitive tools: (a) to take over the low level, tedious, and laborious processes, so as to (b) free up the learners' cognitive sources to engage in higher order thinking with the goal of fostering independent thinkers. Computers help learners engage in constructive thinking and provide scaffolding for cognitive operations that learners would not be able to perform independently. Salomon differentiated between performance-oriented tools and pedagogic tools. Performance-oriented tools enhance the performance of a learner (effect with technology), although the ultimate goal is that the learner would develop the cognition without the aid of the tool (effect of technology). In this way, performance-oriented tools could have learning value and are different from the productivity tools referred to by Jonassen (2000).

It is noteworthy that cognitive tools - for example, Salomon's (1993) Writing Partner and Reusser's (1993) HERON - focus on specific cognitive activities (e.g., writing or mathematics problem-solving) whereas Jonassen's $(1996,2000)$ mindtools are more generic tools for thinking (e.g., semantic networking tools) that focus on knowledge representation applicable for various subject domains. Thus, cognitive tools are domain specific tools (B. Kim \& Reeves, 2007), such as HERON for solving mathematics word problems. In some cases, cognitive tools can be developed to support thinking in a domain (e.g., writing) but not specific skills. B. Kim and Reeves (2007) called these domain generic tools.

From the above description, it is apparent that the underlying motive for using computers as cognitive tools is to scaffold specific thinking processes, so as to help novices develop expertise in a specific domain. While most mindtools (e.g., concept mapping tools) are domain general tools, cognitive tools are usually the outcome of a development process by researchers for a specific purpose (see Figure 3), which involve two closely interlinked activity systems. The tools developed by one community are used by learners in learning contexts.

To achieve the goal of developing expertise among learners, guidance provided in using the tools is critical. The underpinning philosophy is that of neo-Piagetian psychology of developing metacognitive selfregulation (Lajoie \& Derry, 1993), which refers to the ability to consciously reflect on one's problemsolving strategy or knowledge model. Cognitive tools make the abstract strategies concrete for examination and discussion, and thus afford the opportunity for metacognitive regulation. A good tutor or mentor can guide the students in using cognitive tools appropriately for metacognitive regulation. 


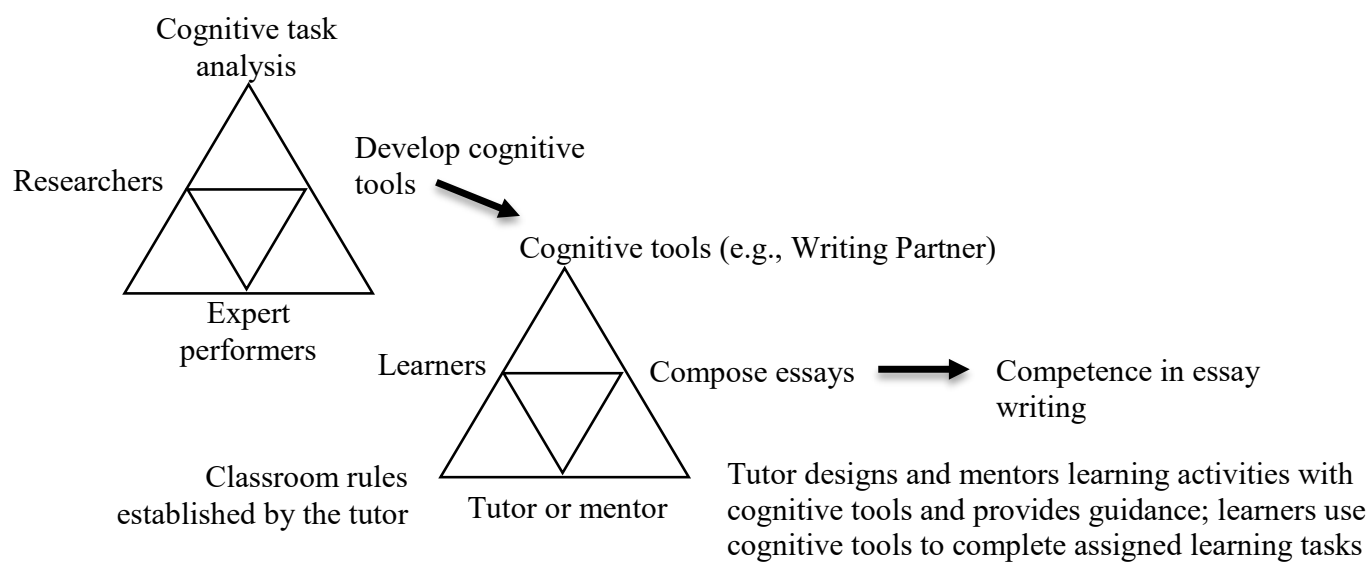

Motive: Developing expertise through cognitive apprenticeship

Figure 3. Activity systems of developing and using computers as cognitive tools

Activity system of using computers as social cognitive tools or social mindtools

While much research on using computers as cognitive tools or mindtools has focused on individual learners, there are research and development efforts to extend this to learning contexts involving social interactions. For example, using online conferencing tools can support learning as "a process of enculturation into a community of learners or practitioners" (Jonassen, 2000, p. 238).

A review of literature shows that studies that featured social cognitive tools or social mindtools in the titles fall into two broad categories: (a) social interactions designed and supported by instructors, and (b) social interactions supported or scaffolded through computers. The first category is exemplified by Hwang, Shi, and Chu (2011), who used mobile technologies and RFID (radio-frequency identification) to support students in context-sensitive learning in a butterfly ecology garden. The elementary school students in the treatment group had to first construct concept maps using a cognitive tool called CMap after learning about ecology in the classroom. The students then visited an ecology garden and edited their concept maps and shared them with their classmates. Although CMap supports collaborative construction of concept maps, this study reported sharing, rather than co-construction, of the concept maps. This category bears strong similarities to the use of cognitive apprenticeship to develop learners' expertise described in the previous section (Activity systems of using computers as cognitive tools). For the second category of supporting interactions via computer tools, Kirschner and Wopereis (2003) reported the use of conversation tools to support teachers' conversation with the goal of building a community of practice (Lave \& Wenger, 1991). The value of the conversation tools is demonstrated in a project called ICT-E-NET(Kirschner \& Wopereis, 2003), which offered four spaces that help to build a professional community (Publication space for references and guidelines, Reflection space for sharing of experiences, Discussion space for conversation, and Construction space for developing new documents).

In terms of scaffolding roles, computer-based cognitive tools that support or scaffold social interactions are merging with a parallel development known as computer-supported collaborative learning (CSCL). CSCL is a rapidly evolving field of study that concerns the design, analysis, and implementation of computer support and collaborative learning (Stahl, Koschmann, \& Suthers, 2015). Considering the broad inclusive nature of the field of CSCL, social cognitive tools or social mindtools can be considered a subset of CSCL tools with a strong emphasis on scaffolding the cognitive processes of learning. According to Stahl et al. (2015), since the beginning of 1990s, CSCL has emerged as a field that highlights the use of networked computers to support collaborative learning, as opposed to predominant e-learning delivery that focuses on transmission of information (learning from computers). Collaborative learning focuses on "individuals negotiat[ing] and shar[ing] meanings relevant to the problem-solving task at hand" through "a coordinated, synchronous activity that is the result of a continued attempt to construct and maintain a shared conception of a problem (Roschelle \& Teasley, 1995, p. 70).

One example of a CSCL tool is Knowledge Forum, which is the brainchild of Scardamalia and Bereiter $(1996,2014)$, who developed the platform in tandem with their development of knowledge building theory 
and pedagogy. Knowledge building is an idea-centric and dialogic approach. It leverages a student's natural curiosity in asking questions and develops that into collaborative inquiry. As students pursue their inquiry, they represent their ideas (e.g., explanations, theory) on Knowledge Forum as notes; through collaborative meaning making, investigation, and learning from authoritative sources of knowledge, they improve their ideas (e.g., developing increasingly better explanations). In this way, the trajectory of collaborative idea improvement is reified in the knowledge artefacts (notes). This approach can be considered dialogic (Wells, 1999) in that it engages the students in dialogues and meaning making, and also empowers them with their voice and choice of inquiry - which is radically different from the predominant teacher-directed pedagogical approaches (e.g., lecture and recitation).

Social cognitive tools or social mindtools are employed to support an activity system in many ways. Like mindtools or cognitive tools, they can scaffold the cognitive processes mediating between subject and object. For example, in Knowledge Forum (Scardamalia \& Bereiter, 1996, 2014), cognitive cues such as "my theory is" and "I need to understand" are often used to support learners in proposing ideas and in thinking deeply about a topic to improve those ideas. Social cognitive tools can also be used to support community rules and division of labour (Nuutinen et al., 2010).

A new class of tools, known as cognitive group awareness tools (Janssen \& Bodemer, 2013), are increasingly being developed. From the perspective of cognitive load theory (Sweller, 2010), group awareness tools help users in reducing the cognitive burden of coordinating and communicating with other group members (Dillenbourg \& Bétrancourt, 2006). The tools work by providing information that may not be apparent to the participating members who are immersed in the interaction process (Janssen \& Bodemer, 2013). In Knowledge Forum, for example, engagement rules are scaffolded by various features. For instance, the Promising Idea tool (Chen, Scardamalia, \& Bereiter, 2015) enables users to highlight ideas that are likely to lead to more fruitful discussion. Learners can build on (reply to) one another's notes but not edit or change the content of others' notes; in cases when more than one author is assigned to a note, all authors can edit the note.

Computers are used as social cognitive tools or social mindtools to integrate social interactions and cognitive scaffolding in learning. In terms of a theoretical underpinning, this use is aligned to a participatory approach to learning (Sfard, 1998) and learning by enculturation into a community (Lave \& Wenger, 1991). Learning through participation entails knowing and building expertise through dialogues with peers and experts in a community, rather than trying to acquire objective knowledge through transmission. In a community of practice, a member starts at the periphery of the community. Participation in the community's activities provides opportunities for members to socially construct meanings and create and appropriate social cultural norms. Over time, a new member begins to appropriate implicit and explicit knowledge, and at the same time, develops expertise and an identity within the community. Much like an apprentice learning from the master, the development of skills, values, norms, and rules held by the core members within the community of practice is a participatory process. A member journeys from the periphery to the centre of the community as he or she develops expertise. The identity of the person gradually develops through the appropriation of the beliefs, values, and skills required in a practice.

In the case of a social cognitive tool (e.g., Scardamalia \& Bereiter, 1996, 2014) or social mindtool (e.g., Hwang, Shi, et al., 2011), if an existing tool is used, the activity system of a social mindtool is similar to that of a mindtool (Figure 2). In some cases like the use of Knowledge Forum, through the use of various research and development methods, a community of researchers has been formed that continue to improve the tool (Knowledge Forum) and the knowledge building pedagogy (rules of engagement and division of labour); consequently, the activity system as depicted in Figure 4, is more complex than that of Figure 3 because the outcomes of the research activity system have impact on the tools, the rules, and division of labour of the application activity system. 


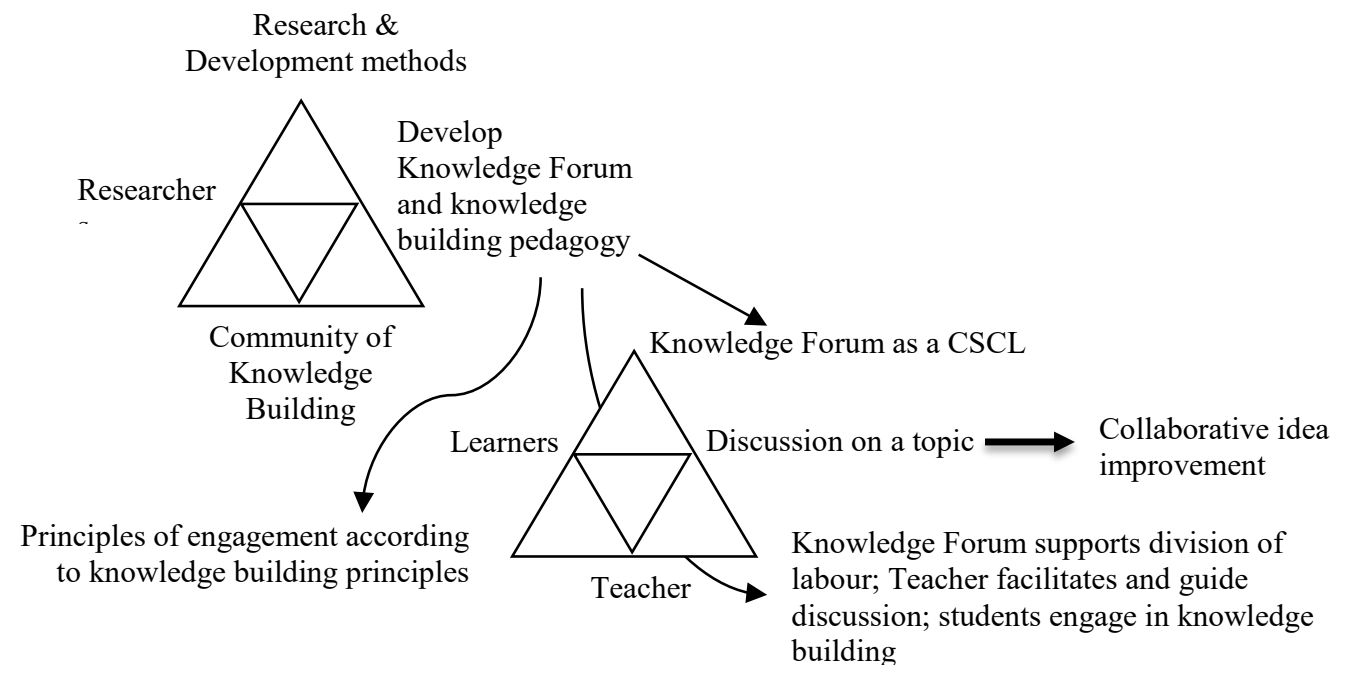

Motive: Integrating social interactions and cognitive thinking; participatory approach and dialogic inquiry

Figure 4. Activity systems of using computers as social cognitive tools or mindtools

\section{Using CHAT analysis for improvement}

CHAT provides a framework for analysing the underlying motives of using computers as tools and how computers can contribute to the various components within an activity system. In addition, an analysis of the contradictions within an activity system can provide critical information for improving the system. Contradictions refers to "historically accumulating structural tensions within and between activity systems" which serve as "sources of change and development" (Engeström, 2001, p. 137). According to Engeström (1987), there are four levels of contradictions: primary, secondary, tertiary, and quaternary. A primary contradiction happens internally within a single node of an activity system where there are "two opposing forces whose interplay leads to a necessity to choose one element of the contradiction over the other" (Holt \& Morris, 1993, p. 100). For example, a teacher who is keen to use Knowledge Forum but still holds the view of learning as acquisition (Sfard, 1998) may use the forum to disseminate information instead of engaging students in collaborative idea improvement (Tan \& Tan, 2006). A secondary contradiction occurs between a pair of nodes. For example, using Knowledge Forum, students found that there are many ideas generated in the initial phase and have challenges prioritising which ideas to work on (Lee \& Tan, 2017a, 2017b). A tertiary contradiction happens when a new object (e.g., a culturally more advanced form of the central activity) is introduced into the system (Engeström, 1987). For example, when introduced to a new tool like Idea Thread Mapper (Zhang et al., 2018), the teacher and students may experience this contradiction of what to work on (object) in order to enhance the knowledge building process. A quaternary contradiction is one that occurs between the central activity and its neighbouring activities that run concurrently and could impact any one component of the activity system. For example, researchers of a knowledge building community could also be members in a learning analytics research community, who can see immediate gaps in the Knowledge Forum tool.

To elaborate on the application of CHAT for improvement, an analysis of some innovations in learning with computers is presented. For example, as mentioned in the preceding paragraph, using CHAT helped to identify the problem of a teacher who used knowledge building pedagogy but still held the view of learning as acquisition, a type of primary contradiction (Tan \& Tan, 2006). With the problem identified, we could then design and evaluate methods to tackle this problem. One way is to get expert teachers to work with novice teachers in a professional learning community to design knowledge building lessons (Tan, Chue, \& Teo 2016). Within the research community of knowledge building, one challenge that has been identified is, given the many ideas generated by students in the initial phase of the process, what can we do to help students proceed to have a more productive discussion? One of the issues is identifying ideas that are more promising (Chen et al., 2015) in bringing the discourse forward. This is an example of a secondary contradiction, where the subjects face challenges in working on the object. More specifically, 
referring to the activity system on the lower right side of Figure 4, how do learners achieve a more fruitful discussion on a topic? To deal with this challenge, Chen et al. (2015) developed a tool for students to highlight and identify promising ideas. To deal with the same problem, Lee and Tan (2017a, 2017b) developed learning analytics solutions for data in Knowledge Forum to help identify ideas that are deemed promising to the community. It uses several techniques, including text mining using the software SOBEK to identify keywords in students' discourse; feeding the keywords into network analysis tools called KBDex (Oshima, Oshima, \& Matsuzawa, 2012); from the results of network analysis, computing betweenness centrality (BC) indices of all the notes in the forum; and finally plotting the BC trends over turns of talk. By examining the $\mathrm{BC}$ trends, notes that play the mediating roles in the discourse (connecting ideas) can be identified. The outcome is the analytic framework and processes (Lee \& Tan, 2017a, 2017b) for promising ideas that researchers could use to advance a knowledge building process.

A tertiary contradiction could lead to the development of new tools and methods. For example, Hwang, Shi, et al. (2011) found that advancement in wireless technologies affords new opportunities for contextsensitive ubiquitous learning (u-learning). They saw opportunities for projected new forms of learning with cognitive tools by integrating various tools and methods. One example is the use of the repertory grid method (cf. expert systems by Jonassen, 2000) and concept mapping tools to engage students in field-based learning (Hwang, Chu, \& Tsai, 2011; Hwang, Hung, Chen, \& Liu, 2014) supported by mobile technologies under a Taiwanese national project called MAIL (mindtool-assisted in-field learning). Students are asked to collect data in real-world environments (e.g., ecology gardens) and classify the data using the repertory grid method or construct concept maps based on the data.

An example of innovation that can be prompted by quaternary contradiction is the development of connectivist massive open online courses or cMOOCs, pioneered by Siemens (2005) and Downes (2012). It is a quaternary contradiction in that cMOOCs present a parallel development (activity system) which integrates learning with computers and learning from computers. In their inaugural cMOOC course called Connectivism and Connective Knowledge (CCK), offered at the University of Manitoba in 2008, about 2300 students took the class for free compared with only 25 registered fee-paying students. The course leveraged various technologies, particularly the connectivity afforded by the Internet and Web 2.0 tools, including curation of information through RSS feeds, Second Life, blog posts in Moodle, and synchronous online meetings. These technologies supported various processes for learning; for example, the aggregation of resources using curation tools helped learners to gain access to a wide range of resources; learners used Web 2.0 tools (e.g., YouTube, blogs, Flickr) both as consumers of resources as well as creators of information (blogs to write reflections). However, some Web 2.0 tools such as Moodle acted more like a learning management system, rather than a mindtool or a cognitive tool. Underpinning cMOOCs is the theory of connectivism (Downes, 2012; Siemens, 2005), which views the Internet as the foundation technology that helps to host knowledge in a distributed and new form of learning entailing the ability to traverse the networks and integrate the distributed knowledge. It is apparent that a cMOOC is aligned to distributed learning (cf. distributed cognition by Pea, 1993) and it departs from learning solely through acquisition. Participatory learning is likely to be a mechanism operating in a cMOOC environment. It is, however, different from most social cognitive tools in terms of scale and open structure; that is, it is not confined to a small group of formal registered students, but open to large numbers of participants who attend for free. In this way, the potential richness of resources and interaction opportunities are manifold, and the empowerment of the students' voice and choice of inquiry can be fully realised. Beyond participatory learning, connectivist learning also emphasises the process of connecting various nodes of information, the ability to see connections among ideas and concepts that may not be apparent at first glance, and the currency of information. With the autonomy given to learners, they will also need to be able to differentiate relevant from irrelevant information, integrate ideas from diverse opinions, and make decisions.

In the above examples, the researchers did not use CHAT explicitly in their analyses. The post-hoc analyses presented above serve to illustrate how CHAT could be used as a lens to identify contradictions so as to reveal areas for improvement. If researchers scan the environment and look beyond the immediate research community, they may find parallel communities that could inspire new ways of learning with computers. One example is learning with computers involving the emotions of learning. The American Psychological Association (1997), in the proposed framework for school reform, listed several key learning principles that highlighted the cognitive, social, and emotional factors of learning. Given the cognitive and social cognitive tools that have emerged, researchers could explore tools that support emotional factors. While much 
educational research has focused on the cognitive and social aspects of learning, research on emotional development among students is only slowly gaining traction (Weissberg, Durlak, Domitrovich, \& Gullotta, 2015). Research has shown that students do experience a range of emotions in academic settings (Pekrun, Goetz, Titz, \& Perry, 2002), which could affect their motivation, learning strategies, cognitive resources, self-regulation, and academic achievement. Practically, neurotechnology, such as electroencephalography (EEG) devices, has been shown to be promising in assessing emotions by analysing the frequency bands of gamma, beta, alpha, theta, and delta (Hu et al., 2017). Researchers have found the combination of gamma and alpha bands to be sensitive to valence and the arousal of emotions (Guzel Aydin, Kaya, \& Guler, 2016). EEG signals can thus be used to collect emotions data from students. This opens the doors to assessing moment-to-moment emotions, and the resulting data can be applied in learning contexts. It can overcome the methodological limitations of measuring students' emotions by retrospective reporting and selfperception of emotional experience after an instructional event is over. Wearable EEG devices (e.g., MUSE) can be used in an unobtrusive and non-threatening manner to collect emotions data in a continuous manner. Potentially, the data can be captured in a way that enables students to monitor their own emotions in learning, as and when they are engaging in learning activities. Apostolidis and Stylianidis (2014), for example, suggested the design for a biofeedback system that could provide feedback on stress levels to students for their self-regulation in a learning context. This could lead to the development of an emotion partner tool in learning.

\section{Conclusion: Insights into the evolution of learning with computers}

This article set out to review the notion of learning with computers, epitomised by using computers as cognitive or mindtools. A common theme in using these tools is the fundamental idea of learning with computers, rather than learning from computers. A tool helps learners to achieve what they would otherwise be unable to achieve (effect with technology), with the ultimate goal that they develop the competency without the aid of the computers (effect of technology). Underpinned by constructivist epistemology (Bednar, Cunningham, Duffy, \& Perry, 1992), such applications also help to develop agency in the learners. With rapid advances in technologies such as CSCL tools and analytics, new affordances and roles of tools become possible (e.g., supporting collaboration and interactions). These changes are accompanied by changes in underpinning theories, extending beyond constructivist theory to social-constructivist, social cultural theory, distributed cognition, and situated cognition.

Using CHAT as an analytical lens, insights into using computers as mindtools, cognitive tools, and social cognitive tools or social mindtools could be generated. CHAT provides the framework and directs our attention to the critical components of activity systems, and how these components work in concert with underlying motives. Consequently, the differences in activity systems can be clarified, as summarised in Table 1 . The activity systems for learning from computers are included in this comparison.

Revisiting M. C. Kim's (2012) call to clarify the concept of cognitive tools, this paper article has shown that the concept is indeed evolving. This is not surprising given that in knowledge creation enterprise like educational research communities, new concepts are always emerging. Even a socially agreed definition at a certain point in time is subject to change and advancement. As the analyses presented in this article show, mindtools and cognitive tools, although similar in many ways, have emerged from different communities and are underpinned by different theories. In addition, the evolution of mindtools and cognitive tools to social mindtools or social cognitive tools and the melding into CSCL tools is seen as a progression of how new knowledge develops. They share that the issues of interactions, dialogues, meaning making, and the distributed nature of knowing are part of the research agenda in CSCL among many researchers. 
Table 1

Main differences in activity systems of computer-assisted instruction, computers as mindtools, computers as cognitive tools, and computers as social mindtools or social cognitive tools

\begin{tabular}{|c|c|c|c|c|}
\hline & $\begin{array}{l}\text { Computer- } \\
\text { assisted } \\
\text { instruction }\end{array}$ & $\begin{array}{l}\text { Computers as } \\
\text { mindtools }\end{array}$ & $\begin{array}{l}\text { Computers as } \\
\text { cognitive tools }\end{array}$ & $\begin{array}{l}\text { Computers as social } \\
\text { mindtools or social } \\
\text { cognitive tools }\end{array}$ \\
\hline $\begin{array}{l}\text { Underlying } \\
\text { motives and } \\
\text { intended learning } \\
\text { outcomes and }\end{array}$ & $\begin{array}{l}\text { Effective } \\
\text { delivery and } \\
\text { acquisition of } \\
\text { content (content } \\
\text { mastery) }\end{array}$ & $\begin{array}{l}\text { Develop critical } \\
\text { thinking through } \\
\text { constructivist } \\
\text { learning }\end{array}$ & $\begin{array}{l}\text { Develop specific } \\
\text { expertise through } \\
\text { cognitive } \\
\text { apprenticeship }\end{array}$ & $\begin{array}{l}\text { Integrate social } \\
\text { interactions and } \\
\text { cognitive thinking for } \\
\text { collaborative idea } \\
\text { improvement }\end{array}$ \\
\hline Tools & $\begin{array}{l}\text { Computers } \\
\text { mimic expert } \\
\text { instructors }\end{array}$ & $\begin{array}{l}\text { Computers act as } \\
\text { intellectual } \\
\text { learning } \\
\text { partners; provide } \\
\text { the environment } \\
\text { and store data. } \\
\text { Mostly general } \\
\text { tools that work } \\
\text { across subject } \\
\text { domains }\end{array}$ & $\begin{array}{l}\text { Computers act as } \\
\text { intellectual } \\
\text { learning partners; } \\
\text { provide the } \\
\text { environment and } \\
\text { store data. Mainly } \\
\text { domain generic or } \\
\text { domain specific to } \\
\text { develop specific } \\
\text { expertise. }\end{array}$ & $\begin{array}{l}\text { Computers act as } \\
\text { intellectual learning } \\
\text { partners; provide the } \\
\text { environment and store } \\
\text { data. Could be general } \\
\text { tools, domain generic } \\
\text { or domain specific } \\
\text { tools. Include support } \\
\text { for collaboration, } \\
\text { rules or division of } \\
\text { labours }\end{array}$ \\
\hline Community & $\begin{array}{l}\text { Teacher and } \\
\text { students (using } \\
\text { tools developed } \\
\text { by others) }\end{array}$ & $\begin{array}{l}\text { Teacher and } \\
\text { students (using } \\
\text { tools developed } \\
\text { by others) }\end{array}$ & $\begin{array}{l}\text { Researcher } \\
\text { community } \\
\text { working in } \\
\text { tandem with } \\
\text { experts, teachers, } \\
\text { and students }\end{array}$ & $\begin{array}{l}\text { Researcher } \\
\text { community working } \\
\text { in tandem with } \\
\text { experts, teachers, and } \\
\text { students }\end{array}$ \\
\hline $\begin{array}{l}\text { Underlying } \\
\text { theories }\end{array}$ & Objectivist & $\begin{array}{l}\text { Constructivist } \\
\text { learning }\end{array}$ & $\begin{array}{l}\text { Social } \\
\text { constructivist; } \\
\text { distributed } \\
\text { cognition }\end{array}$ & $\begin{array}{l}\text { Participatory learning; } \\
\text { community of } \\
\text { practice; learning } \\
\text { through knowledge } \\
\text { creation }\end{array}$ \\
\hline
\end{tabular}

Using CHAT as an analytical lens, this article contributes to the field by clarifying the nuanced differences between various applications of learning with computers, including the roles of tools, the distribution of roles among members, the overlapping activity systems involved in the innovation, and the underlying theories and motives of the communities. Indeed, the various applications of learning with computers, rather than from computers, have withstood the test of time over the past few decades. Recent advancements in technologies offer new promises, such as the use of learning analytics to afford self-assessment opportunities, integration of various tools to provide hybrid learning environments, and the possibility of developing emotion tools for learning. This article has also proposed using CHAT as the framework to analyse the contradictions within and beyond an activity system, so that these contradictions can reveal opportunities for improvement or innovation. It is hoped that such as an approach will propel this line of research and development to a greater height.

\section{References}

American Psychological Association. (1997). Learner-centred psychological principles: A framework for school reform and redesign. Washington, DC: Center for Psychology in Schools and Education.

Apostolidis, H., \& Stylianidia, P. (2014). Designing a mobile bio-feedback device to support learning activities. In IMCL2014. Proceedings of the 2014 International Conference on Interactive Mobile Communication Technologies and Learning (pp. 189-194). IEEE. https://doi.org/10.1109/IMCTL.2014.7011129

Bednar, A. K., Cunningham, D., Duffy, T. M., \& Perry, J. D. (1992). Theory into practice: How do we link? In T. M. Duffy \& D. H. Jonassen (Eds.), Constructivism and the technology of instruction: A conversation (pp. 17-34). Hillsdale, NJ: Lawrence Erlbaum Associates. 
Bereiter, C., \& Scardamalia, M. (1987). The psychology of written composition. Hillsdale, NJ: Lawrence Erlbaum Associates.

Chen, B., Scardamalia, M., \& Bereiter, C. (2015). Advancing knowledge: building discourse through judgments of promising ideas. International Journal of Computer-Supported Collaborative Learning, 10(4), 345-366. https://doi.org/10.1007/s11412-015-9225-z

Cole, M., \& Engeström, Y. (1993). A cultural-historical approach to distributed cognition. In G. Salomon (Ed.), Distributed cognition: Psychological and educational considerations (pp. 1-46). New York, NY: Cambridge University Press.

Dillenbourg, P., \& Bétrancourt, M. (2006). Collaboration load. In J. Elen \& R. E. Clark (Eds.), Handling complexity in learning environments: Research and theory (pp. 142-163). Amsterdam, The Netherlands: Elsevier.

Downes, S. (2012). Connectivism and connective knowledge: Essays on meaning and learning network. Ottawa, Canada: National Research Council. Retrieved from https://oerknowledgecloud.org/sites/oerknowledgecloud.org/files/Connective_Knowledge19May2012.pdf

Duffy, T. M., \& Jonassen, D. H. (Eds.). (1992). Constructivism and the technology of instruction: A conversation. Hillsdale, NJ: Lawrence Erlbaum Associates.

Engeström, Y. (1987). Learning by expanding: An activity-theoretical approach to developmental research. Helsinki, Finland: Orienta-Konsultit.

Engeström, Y. (1999). Communication, discourse and activity. The Communication Review, 3(1-2), 165185. https://doi.org/10.1080/10714429909368577

Engeström, Y. (2001). Expansive learning at work: Toward an activity-theoretical conceptualization. Journal of Education and Work, 14(1), 133-156. https://doi.org/10.1080/13639080020028747

Guzel Aydin, S., Kaya, T., \& Guler, H. (2016). Wavelet-based study of valence-arousal model of emotions on EEG signals with LabVIEW. Brain Inform, 3(2), 109-117. https://doi.org/10.1007/s40708-016-0031-9

Holt, G. R., \& Morris, A. W. (1993). Activity theory and the analysis of organizations. Human Organization, 52(1), 97-109. https://doi.org/10.17730/humo.52.1.u305r18277724374

Hu, X., Yu, J., Song, M., Yu, C., Wang, F., Sun, P., ... Zhang, D. (2017). EEG correlates of ten positive emotions. Frontier in Human Neuroscience, 11. https://doi.org/10.3389/fnhum.2017.00026

Hwang, G.-J., Chu, H.-C., \& Tsai, C.-C. (2011). A knowledge acquisition approach to developing mindtools for organizing and sharing differentiating knowledge in a ubiquitous learning environment. Computers \& Education, 57(1), 1368-1377. https://doi.org/10.1016/j.compedu.2010.12.013

Hwang, G.-J., Hung, P.-H., Chen, N.-S, Liu, G.-Z. (2014). Mindtool-assisted in-field learning (MAIL): An advanced ubiquitous learning project in Taiwan. Educational Technology \& Society, 17(2), 4-16. Retrieved from http://www.jstor.org/stable/jeductechsoci.17.2.4

Hwang, G-J., Shi, Y-R., Chu, H-C. (2011). A concept map approach to developing collaborative Mindtools for context-aware ubiquitous learning. British Journal of Educational Technology, 42(5), 778-789. https://doi.org/10.1111/j.1467-8535.2010.01102.x

Janssen, J., \& Bodemer, D. (2013). Coordinated computer-supported collaborative learning: Awareness and awareness tools. Educational Psychologist, 48(1), 40-55. https://doi.org/10.1080/00461520.2012.749153

Jonassen, D. H. (1996). Computers in the classroom: Mindtools for critical thinking. Columbus, $\mathrm{OH}$ : Merrill/Prentice Hall.

Jonassen, D. H. (2000). Computers as mindtools for schools: Engaging critical thinking (2nd ed.). Upper Saddle River, NJ: Prentice Hall.

Kim, B., \& Reeves, T. (2007). Reframing research on learning with technology: In search of the meaning of cognitive tools. Instructional Science, 35(3), 207-256. https://doi.org/10.1007/s11251-006-9005-2

Kim, M. C. (2012). Revisiting cognitive tools: Shifting the focus to tools-in-use. Educational Technology, 52(4), 14-24. Retrieved from https://www-jstor-org.libproxy.nie.edu.sg/stable/44430054

Kirschner, P., \& Wopereis, I. G. J. H. (2003). Mindtools for teacher communities: a European perspective. Technology, Pedagogy and Education, 12(1), 105-124. https://doi.org/10.1080/14759390300200148

Kommers, P. A. M., Jonassen, D. H., \& Mayes, T. (Eds.). (1992). Cognitive tools for learning. Berlin, Germany: Springer.

Kozulin, A. (1986). The concept of activity in Soviet psychology: Vygotsky, his disciples and critics, American Psychologist, 41, 264-274. https://doi.org/10.1037/0003-066X.41.3.264 
Lajoie, S. P. (Ed.). (2000). Computers as cognitive tools: No more walls. Mahwah, NJ: Lawrence Erlbaum Associates.

Lajoie, S. P., \& Derry, S. J. (Eds.). (1993). Computers as cognitive tools. Mahwah, NJ: Lawrence Erlbaum Associates.

Lave, J., \& Wenger, E. (1991): Situated learning: Legitimate peripheral participation. Cambridge, England: Cambridge University Press.

Lee, A. V. Y., \& Tan, S. C. (2017a). Promising ideas for collective advancement of communal knowledge using temporal analytics and cluster analysis. Journal of Learning Analytics, 4(3), 76-101. https://doi.org/10.18608/jla.2017.43.5

Lee, V. Y. A., \& Tan, S. C. (2017b). Understanding idea flow: Applying learning analytics in discourse. Learning: Research \& Practice, 3(1), 12-29. https://doi.org/10.1080/23735082.2017.1283437

Li, Y., Sun, J., \& Sun, M. Y. (2018). Analysis of the development status and impact of MOOCs in American higher education. Educational Sciences: Theory \& Practice, 18(6), 3442-3448. https://doi.org/10.12738/estp.2018.6.251

Novak, J. D., \& Gowin, D. B. (1984). Learning how to learn. New York, NY: Cambridge University Press.

Nuutinen, J., Sutinen, E., Botha, A., \& Kommers, P. (2010). From mindtools to social mindtools: Collaborative writing with Woven Stories. British Journal of Educational Technology, 41(5), 753775. https://doi.org/10.1111/j.1467-8535.2009.00973.x

Oshima, J., Oshima, R., \& Matsuzawa, Y. (2012). Knowledge Building Discourse Explorer: A social network analysis application for knowledge building discourse. Educational Technology Research and Development, 60(5), 903-921. https://doi.org/10.1007/s11423-012-9265-2

Pea. R. D. (1985). Beyond amplification: Using the computer to reorganize mental functioning. Educational Psychologist, 20, 167-182. https://doi.org/10.1207/s15326985ep2004

Pea, R. D. (1993). Practices of distributed intelligences and design for education. In G. Solomon (Ed.), Distributed cognitions: Psychological and educational considerations (pp. 47-87). Cambridge, England: Cambridge University Press.

Pekrun, R., Goetz, T., Titz, W., \& Perry, R. P. (2002). Academic emotions in students' self-regulated learning and achievement: A program of qualitative and quantitative research. Educational Psychologist, 37, 91-106. https://doi.org/10.1207/S15326985EP3702_4

Perkins, D. N. (1985). The fingertip effects: How information-processing technology shapes thinking. Educational Researcher, 14(7), 11-17. https://doi.org/10.3102/0013189X014007011

Reusser, K. (1993). Tutoring systems and pedagogical theory: Representational tools for understanding, planning and reflection in problem solving. In S. P. Lajoie \& S. J. Derry (Eds.), Computer as cognitive tools (pp. 143-178). Hillsdale, NJ: Lawrence Erlbaum Associates.

Roschelle, J., \& Teasley, S. (1995). The construction of shared knowledge in collaborative problem solving. In C. O’Malley (Ed.), Computer-supported collaborative learning (pp. 69-197). Berlin, Germany: Springer Verlag.

Salomon, G. (1993). On the nature of pedagogic computer tools: The case of Writing Partner. In S. P. Lajoie \& S. J. Derry (Eds.), Computer as cognitive tools (pp. 179-196). Hillsdale, NJ: Lawrence Erlbaum Associates.

Salomon, G., Perkins, D. N., \& Globerson, T. (1991). Partners in cognition: Extending human intelligence with intelligent technologies. Educational Researcher, 20(3), 2-9. https://doi.org/10.3102/0013189X020003002

Scardamalia, M., \& Bereiter, C. (1996). Computer support for knowledge-building communities. In T. Koschmann (Ed.), CSCL: Theory and practice of an emerging paradigm (pp. 249-268). Mahwah, NJ: Lawrence Erlbaum Associates.

Scardamalia, M., \& Bereiter, C. (2014). Knowledge building: Theory, pedagogy, and technology. In Sawyer, R. K. (Ed.). The Cambridge handbook of the learning sciences (2nd ed., pp. 397-417). New York, NY: Cambridge University Press.

Sfard, A. (1998). On two metaphors for learning and the dangers of choosing just one. Educational Researcher, 27(2), 4-13. https://doi.org/10.3102/0013189X027002004

Siemens, G. (2005). Connectivism: A learning theory for the digital age. International Journal of Instructional Technology and Distance Learning, 2(1), 3-10. https://doi.org/10.3109/0142159X.2016.1173661

Stahl, G., Koschmann, T., \& Suthers, D. (2015). Computer-supported collaborative learning. In Sawyer, R. K. (Ed.). The Cambridge handbook of the learning sciences (2nd ed., pp. 479-500). New York, NY: Cambridge University Press. 
Suri, H., \& Clarke, D. (2009). Advancements in research synthesis methods: From a methodologically inclusive perspective. Review of Educational Research, 79(1), 359-430. https://doi.org/10.3102/0034654308326349

Sweller, J. (2010). Element interactivity and intrinsic, extraneous and germane cognitive load. Educational Psychology Review, 22, 123-138. https://doi.org/10.1007/s10648-010-9128-5

Tan, S. C., Chue, S., \& Teo, C. L. (2016). Teacher learning in a professional learning community: Potential for a dual-layer knowledge building. In C. K. Looi, J. Polman, U. Cress, \& P. Reimann (Eds.), Transforming Learning, Empowering Learners. Proceedings of the 12th International Conference of the Learning Sciences (Vol. 1, pp. 178-185). Singapore: International Society of the Learning Sciences, Inc. Retrieved from https://www.isls.org/icls/2016/docs/ICLS2016_Volume 1 30June2016.pdf

Tan, A. L., \& Tan, S. C. (2006). 'But I have not started teaching!': Knowledge building perils. In Y. J. Lee, A. L. Tan, \& B. T. Ho (Eds.), Proceedings of the International Science Education Conference (pp. 840-848). Singapore: National Institute of Education.

Taylor, R. P. (Ed.). (1980). The computer in school: Tutor, tool, tutee. New York, NY: Teachers College Press.

Vygotsky, L. (1978). Mind in society: The development of higher psychological processes. Cambridge, MA: Harvard University Press.

Weissberg, R. P., Durlak, J. A., Domitrovich, C. E., \& Gullotta, T. P. (2015). Social and emotional learning: Past, present, and future. In J. A. Durlak, R. P. Weissberg, \& T. P. Gullotta (Eds.), Handbook of social and emotional learning: Research and practice (pp. 3-19). New York, NY: Guilford.

Wells, G. (1999). Dialogic inquiry: Toward a sociocultural practice and theory of education. Cambridge, England: Cambridge University Press.

Zhang, J., Tao, D., Chen, M.-H., Sun, Y., Judson, D., \& Naqvi, S. (2018). Co-organizing the collective journey of inquiry with Idea Thread Mapper. Journal of the Learning Sciences, 27(3), 390-430. https://doi.org/10.1080/10508406.2018.1444992

Corresponding author: Seng-Chee Tan, sengchee.tan@nie.edu.sg

Please cite as: Tan, S. C. (2019). Learning with computers: Generating insights into the development of cognitive tools using cultural historical activity theory. Australasian Journal of Educational Technology, 35(2), 25-38. https://doi.org/10.14742/ajet.4848 